Relations industrielles

Industrial Relations

Corporate-Subsidiary Relations, Local Contexts and Workplace

Change in Global Corporations

Les relations entre sièges sociaux et succursales et les

contextes locaux comme facteurs de changement

Las relaciones entre las corporaciones y sus subsidiarias y el contexto local como factores que modelan el cambio en el ambiente de trabajo en las corporaciones transnacionales

Stephen J. Frenkel et Carol Royal

Volume 53, numéro 1, hiver 1998

La mondialisation, le travail et les relations industrielles

Globalization, Work and Industrial Relations

URI : https://id.erudit.org/iderudit/005277ar

DOI : https://doi.org/10.7202/005277ar

Aller au sommaire du numéro

Éditeur(s)

Département des relations industrielles de l'Université Laval

ISSN

0034-379X (imprimé)

1703-8138 (numérique)

Découvrir la revue

Citer cet article

Frenkel, S. J. \& Royal, C. (1998). Corporate-Subsidiary Relations, Local Contexts and Workplace Change in Global Corporations. Relations industrielles /

Industrial Relations, 53(1), 154-182. https://doi.org/10.7202/005277ar

Tous droits réservés (C) Département des relations industrielles de l'Université Laval, 1998
Ce document est protégé par la loi sur le droit d'auteur. L'utilisation des services d'Érudit (y compris la reproduction) est assujettie à sa politique d'utilisation que vous pouvez consulter en ligne.

https://apropos.erudit.org/fr/usagers/politique-dutilisation/ 


\title{
Corporate-Subsidiary Relations, Local Contexts and Workplace Change in Global Corporations
}

\author{
STEPHEN J. FRENKEL
}

Centre for Corporate Change, Australian Graduate School of Management, University of New South Wales, Sydney, Australia.

\section{CAROL ROYAL}

Centre for Corporate Change, Australian Graduate School of Management, University of New South Wales, Sydney, Australia.

This paper studies workplace change in two subsidiaries of a multinational corporation. We show how variations in subsidiary relations with corporate headquarters reflect differences in the strategic power and resources of subsidiaries, as well as differences of a local nature. These differences are reflected in variations in the scope, pace and content of workplace change.

Over the past decade multinational corporations (MNCs) have been repositioning and reorganizing as national trade barriers are removed and global competition intensifies. Changes in business strategy and organization have entailed new alignments between subsidiaries and corporate headquarters and between subsidiaries themselves. Together with changes in local environments, which are in turn shaped by international and national economic and political factors, these developments are likely to have far-reaching consequences for work organization and labour relations - or what we refer to as workplace relations. This is the subject of the present paper.

- We would like to thank the managers and workers of "PH" corporation for their cooperation and David Peetz for permitting us to adapt and use his survey instrument. Thanks also to the anonymous reviewers and editors who made valuable comments on a previous draft. 
In attempting to understand and explain workplace change, we draw on a line of inquiry developed by corporate strategy scholars who suggest that subsidiaries vary in their strategic power and in their competencies and resources and hence have different relationships with corporate headquarters (Bartlett and Ghoshal 1989, 1990; Ghoshal and Nohria 1993). We nevertheless take seriously Ferner's (1994) observation that typologies of these relations tend to be static and fail to explain management processes. Our focus is therefore on management's role in changing workplace relations in subsidiaries. We suggest that these vary according to the role of subsidiaries in relation to corporate headquarters, and in response to local factors.

This argument is illustrated by reference to two affiliates in a large pharmaceutical corporation (hereafter referred to as $\mathrm{PH}$ ). One affiliate is located in Britain (U.K.), the other in South Africa (S.A.). The former subsidiary can be characterized as a "local implementer" in the process of becoming a "strategic leader," i.e., gaining in strategic position and in resources (Bartlett and Ghoshal 1989), a tendency strongly encouraged by corporate management. The latter subsidiary was moving in a similar direction, however local management was restricted in its efforts to reposition the affiliate beyond its "local implementer" status. By 1995 it could be characterized as a "restricted local innovator," indicating a limited increase in resources and competencies and pursuing opportunities aimed at improving its strategic position within the corporation. Although managers at both establishments favoured the introduction of just-in-time production, change was articulated in terms of specific initiatives rather than as part of a broader manufacturing strategy. We contrast and explain the implementation of various initiatives at the two plants, including differences in the speed and scope of change, by reference to the variations in the strategic centrality and resourcing of the two affiliates.

The paper begins with a brief discussion of theoretical and methodological issues and introduces the two workplaces. This is followed by a brief outline of the main forces affecting competition in the rapidly globalizing pharmaceutical industry, showing how these pressures led PH corporate management to adopt new strategies and introduce major organizational change. In the third section we show how this corporate context, together with local factors, combined differently to shape workplace management's change priorities in the two plants. In brief, while U.K. management was being strongly encouraged to integrate their operations within a broader European strategy, S.A. management received less attention and support from corporate headquarters (CHQ). Paradoxically, this meant more autonomy (except in human resource 
management), however, with limited resources, a small local market and political uncertainty, S.A. management had rather less incentive and limited opportunities to introduce wide-ranging workplace change. In the fourth section, we contrast the changes actually introduced by local management at the two workplaces and argue that the nature and pace of change reflect the history and characteristics of local management and different headquarters-subsidiary relationships. In the concluding section, we draw out some of the main points of our analysis in the form of conjectures for further discussion and empirical investigation. We also suggest that future research on workplace change might profit from more complex models of organizational relationships and local contexts.

\section{THEORY AND METHODOLOGY}

Four dominant approaches to workplace change can be distinguished. The first avenue of inquiry has been to concentrate on workplaces of MNCs, particularly around the issue of Japanization or the diffusion of just-in-time or lean production (Elger and Smith 1994; MacDuffie 1996). A second thrust has been to examine factors influencing the extent of (de)centralization of human resources (HR) decisions (Marginson et al. 1988: ch. 7; Rosenzweig and Nohria 1994) while a third approach explores the impact of corporate dynamics on workplace relations in MNCs (Frenkel 1994, 1995; Mueller and Purcell 1992). A fourth perspective focuses on corporate management, investigating how power is exercised, particularly around employment relations, and channels of employee participation (Ferner and Edwards 1995; Collier and Marginson 1996). The first approach leaves out of account corporate dynamics - a potentially important explanatory variable - while the second approach is unconcerned with the process of change. The final two perspectives are the obverse of the two first: they tend to privilege corporate rather than local factors in explaining changes in workplace relations. Our concern in this paper is to provide a more balanced account, that is, to explain workplace change as a consequence of the interrelationships between corporate, subsidiary and workplace level dynamics. Figure 1 summarizes the framework that emerged in the course of undertaking this research.

Figure 1 identifies three analytically distinct levels at which pressures for change emerge. At the corporate level, senior management respond to changes in the global industry by developing strategies that set the context for action at lower levels of the corporation. In effect, local managers develop business strategies that are consistent with corporate strategy and associated controls while also catering to the demands of the 
local environment. Manufacturing and HR managers at the workplace level operate within these constraints. They develop strategies and structures, build up competencies and mobilize support that affects workers' and unions' approaches and responses. The outcome of these interactions is change, which over time assumes a discernible pattern or trajectory whose effectiveness tends to be evaluated according to criteria that reflect management and workers' values. Thus, assessments of change may differ. In a similar vein, there is a good deal of varying interpretations and sometimes significant negotiation over strategy. Hence the reverse arrows shown in figure 1, - which, however, are not intended to suggest that bottom-up influences are as powerful as those emanating from higher levels of the corporation. A final point is that strategy implementation is often slow and piecemeal so giving reality a fuzziness that contrasts with the rational, holistic patterning of a systematic plan. Hence, it is important to bear in mind that in characterizing workplace change, we are attempting to simultaneously remain close to the data and present our findings in a way that is amenable to comparative analysis.

\section{FIGURE 1}

Framework for Analyzing Workplace Change in Subsidiaries of Multinational Corporations

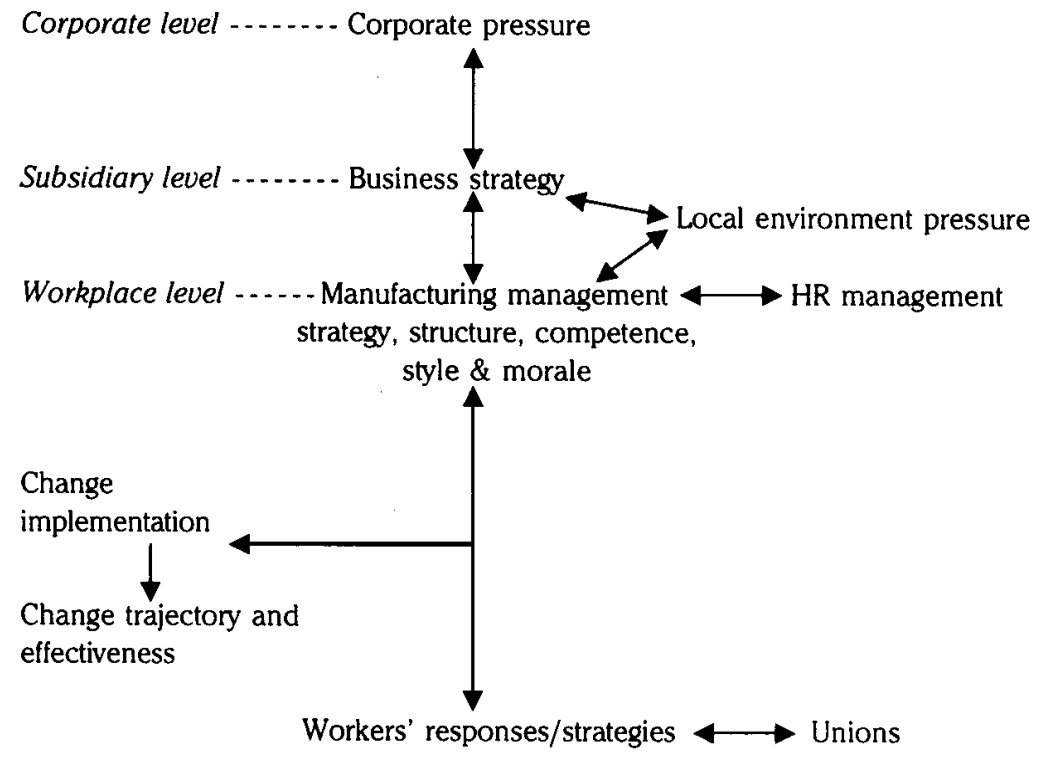


Data for this article was collected from a variety of sources during visits to the workplaces and to regional and corporate headquarters in 1990-1995. During this period, one of the researchers spent a total of three continuous weeks at each workplace observing and interviewing line management, human resource managers and shop stewards. Documentary data on corporate restructuring, workplace change and labour relations were collected at workplace and corporate levels. A survey based on a random sample of one in six and one in three manual workers and their supervisors was undertaken at the U.K. and S.A. plants respectively. The research forms part of a wider study of labour relations in a leading multinational corporation (see Frenkel 1994, 1995; Frenkel and Royal forthcoming).

In 1991 the U.K. pharmaceutical site (which was part of a larger complex) comprised 532 employees, 71 percent of whom worked in manufacturing. The remainder were mainly employed in distribution. The U.K. plant manufactured a more diverse range of products than the S.A. plant, although the technology was similar. Manufacturing and HR management reported to the U.K. national office (which has recently started to report to an enlarged European regional centre) and from there to CHQ. The S.A. plant was situated at the subsidiary headquarters site. Until 1992 management had been reporting to the U.K. national office, but following a restructuring, both manufacturing and human resource managers reported directly to CHQ. Three hundred and twenty eight employees worked on the site, 162 (51 percent) of whom were employed in manufacturing, the remainder working in marketing, finance and distribution.

Around two-thirds of manufacturing employees at both workplaces were semi-skilled workers, and approximately half of these workers were women. While U.K. workers and managers were mainly Welsh, S.A. workers were virtually all "coloured," working under predominantly white managers. U.K. workers were on average younger and had been employed at the company for a shorter period than their S.A. counterparts (Frenkel and Royal forthcoming). Union density was close to 100 percent at the U.K. plant and around 75 percent in S.A., but this has very recently (1996) declined to slightly over 50 percent. Both plants are located outside urban areas where unemployment has traditionally been high. In S.A., unemployment was around 40 percent while in the U.K. the corresponding figure in 1995 was 10 percent, with a tendency to decline as low land prices and wage rates, compared to other European countries, attracted new investment. 


\section{CORPORATE-LEVEL RESPONSES TO GLOBALIZATION IN THE}

\section{PHARMACEUTICAL INDUSTRY}

$\mathrm{PH}$ is among the 15 largest and most profitable MNCs in the global pharmaceutical industry. In 1995, the company's annual turnover exceeded \$US 7,000 million and the corporation employed nearly 37,000 employees working in over 40 countries. Notwithstanding some important variations, subsidiaries in various parts of the world produce and market similar items. On account of the relatively large proportion of sales revenue derived from non-prescription goods (see below), PH is best described as a diversified pharmaceutical company.

Like other pharmaceutical firms, $\mathrm{PH}$ experienced a profit squeeze in the early 1990s. This was attributed to a number of factors: stricter government monitoring and control of health expenditures and raising of drug manufacturing standards; the emergence of medical health organizations to contain escalating health costs, especially in the U.S.; the expiry of patent rights on highly profitable drugs, which left companies exposed to competition from low-cost generics; and limited breakthroughs in introducing new drugs capable of earning "blockbuster" profits. In the meantime, the on-going process of harmonizing national pharmaceutical regulations, particularly in Europe, encouraged competition and put further pressure on companies to rationalize their production and distribution systems.

PH senior management responded to these changes by embarking on a strategy to reposition and restructure the corporation. In 1990, the new global strategy celebrated the notion that each product was a global opportunity that would attract appropriate investment for expanding international sales. Accordingly, over-the-counter (OTC) products were targeted, particularly in large regional markets such as the E.U., Eastern Europe and East Asia. Indeed, PH entered into several large-scale strategic alliances aimed at increasing the flow of prescription drugs into the OTC pipeline (facilitated by changes in drug regulations) and by widening the OTC product range. These alliances also enabled the company to take advantage of established marketing networks developed by their new partners, particularly in Europe. In 1992, nearly 60 percent of PH's revenue came from the sale of non-prescription consumer health care and confectionery products, increasing to 67 percent by 1995. By that date, around 40 percent of total revenue derived from sales in Europe and East Asia.

Organizational restructuring has accelerated in recent years. As markets outside the U.S. expanded relative to the domestic market, management reorganized the company, first along regional lines and 
then, beginning in the 1990s, according to a combination of regions and product groups. $\mathrm{PH}$ is now something of a hybrid regional/global corporation with strategic power shared between CHQ and regional business centres (Frenkel and Royal 1997). In general, subsidiaries became less subject to bureaucratic control from CHQ or regional centres; the emphasis switched to giving subsidiaries slightly more autonomy. Financial controls remained and were supplemented by a new management performance system that embodied common values. However, subsidiaries varied in their relations with CHQ depending on the extent to which corporate management accorded strategic significance to a subsidiary. This typically reflected the subsidiary's actual or potential role in supplying a large or fast-growing market. Thus, as explained below, the U.K. plant in this study was considered to be strategically more important than its S.A. counterpart.

Under the banner of cost reduction, organizational restructuring was directed to eliminating so-called bureaucracy. Consequently, CHQ staff were cut by 30 percent over five years. Other rationalizing strategies targeted purchasing and production. A global purchasing strategy was introduced leading to the closure of several chemical facilities and the concentration of production in two main locations. Subsidiaries were encouraged to communicate their manufacturing requirements to one another in order to achieve greater product specialization and absorb surplus manufacturing capacity. A major thrust has been to improve productivity and quality, largely by concentrating manufacturing in fewer upgraded plants. ${ }^{1}$ In the mid-1990s this became a priority following costly problems in meeting North American government quality standards in some of the company's U.S. workplaces.

The scale of restructuring has been massive. In the period 1991-1993, PH senior management earmarked nearly $\$ 1,000$ million for rationalization of $\mathrm{CHQ}$, manufacturing and distribution. Restructuring of both CHQ and subsidiaries, mainly in North and South America and Europe, has in the short term adversely affected shareholders and employees. Thus, in 1991, a charge of over $\$ 500$ million was made in order to pay for the shutdown of 12 manufacturing facilities and the loss of nearly 2,000 positions. In 1993, there was a further charge of a similar magnitude aimed at rationalizing manufacturing facilities, including the

1. In this regard $\mathrm{PH}$ corporate management followed the advice of McKinsey management consultants (Keene et al. 1990) who advocated a total of between 10 to 15 plants per global pharmaceutical firm. McKinsey's identified three restructuring mechanisms: plant closure in non-strategic markets; reduction in size of plants serving local markets; and concentration of investment in key regional plants. 
closure of seven plants and the loss of nearly 3,000 jobs. ${ }^{2}$ Job reductions were continuing through 1996, more recently involving sales staff, and further plant closures were planned.

Restructuring appears to have contributed significantly to corporate and manufacturing performance. Net sales (unadjusted for inflation) have grown nearly three-fold over the 17-year period (1978-95) and net operating profits as a proportion of identifiable assets has nearly doubled. Manufacturing efficiency, as measured by cost of goods (manufacturing costs as a percentage of net sales), has been reduced from 57 percent to 34.5 percent over the same period and there were 36.2 percent fewer employees in 1995 than in 1978. PH's workforce is now concentrated in fewer countries, although its international sales have expanded relative to U.S. sales. ${ }^{3} \mathrm{PH}$ has nevertheless fallen slightly behind relative to its U.S.based competitors. Thus, PH's ranking in the Fortune pharmaceutical league table in 1995, in terms of both sales and total return to investors, was slightly lower than in 1983 when figures first became available (Fortune 1984, 1995). ${ }^{4}$ Clearly, whatever changes have been made, these have not been enough to stay ahead of the competition.

In sum, PH has been undergoing major change in response to more intense global competition. Repositioning and restructuring have affected subsidiaries and manufacturing plants in different ways. Indeed, as we shall see, compared to their S.A. counterparts, U.K. plant managers were put under considerable pressure to restructure and improve performance, leading to more comprehensive plans for workplace change in the U.K. The following section details these pressures on U.K. management and contrasts them with the S.A. subsidiary, where a desire to increase revenue in a small market and to contain incipient worker militancy, led management to introduce an employee involvement scheme and major labour relations reforms.

2. Severance and related costs were planned to account for 43.8 percent of total 1991 and 1993 restructuring costs.

3. The geographical distribution of employment in 1992 (the most recent year for which figures are available) was as follows: North America 41.5 percent; Europe 21.8 percent; Central and South America 21.7 percent; Asia 12.0 percent; and the Middle East and Africa 3.4 percent.

4. The extent of industry-wide gains in value added per employee through rationalization (including automation) can be gleaned from the following figures. In the period 199095, total sales of the 14 largest U.S. pharmaceutical companies increased at an estimated average of 12.5 percent a year while the average growth of the workforce of these same 14 companies was only 1.3 percent a year (see Fortune 1991: 144, 1996: F59). 
LOCAL MANAGEMENT: PRESSURES AND PRIORITIES FOR CHANGE

CHQ and European regional management regarded the U.K. workplace as central to the company's emerging European strategy. In an effort to promote change, a committee comprising senior European managers (including the new U.K. plant manufacturing director) had devised a strategy to "rationalize and revitalize" manufacturing. According to well-placed sources, the committee had decided that of the twelve plants that existed in Western Europe only three streamlined plants producing specialized products would remain until the year 2000. Thus, for the foreseeable future, the U.K. plant was to be retained as a smaller, restructured, yet more strategically important facility.

\section{The U.K. Subsidiary: From Local Parochialism to Corporate Integration}

Corporate management's confidence that the U.K. plant could be rapidly and successfully restructured stemmed from a particular, historical interpretation of the plant's problems. In order to understand this, we need to go back to 1971 when the plant was established following a merger of the two main companies which now comprise PH. During the 1970s, wage rates at the U.K. plant were relatively low compared to local firms. It was not long before the plant was unionized with workplace unionism consolidated under the leadership of an experienced convener (full-time steward). These developments resulted in the negotiation of more favourable terms and conditions of employment for manual workers.

Management accommodated to a strong union presence while profitability remained high, but later came to question the unions' position as the 1980s recession and other factors adversely affected business. Meanwhile, $\mathrm{PH}$ was manufacturing pharmaceuticals at a second U.K. plant. Factories producing non-pharmaceutical products were also established in Britain. In 1986, following two years' uncertainty, regional management, with corporate consent, decided to close the second plant, a decision prompted by overcapacity in an increasingly competitive market. According to senior managers, the choice of plant for closure reflected relative land prices rather than comparative performance. Indeed, the second plant was said to be more efficient than the surviving facility.

The closure resulted in 450 redundancies, although 250 new jobs were created at the remaining U.K. plant, which became the sole 
pharmaceutical manufacturing facility in Britain. Twenty-seven former employees at the closed plant were relocated to the U.K. plant, including 12 managers. Machinery and equipment were also transferred. Following a successful two-year consolidation period, the plant's manufacturing director was given wider responsibilities that led to a loss of commitment and focus on developing a manufacturing and investment strategy for the plant. In the words of a senior plant manager: "We had lacked the courage to ask for investment funds. The projects we put forward and the amounts we requested didn't do justice to what needed to be done. This was related to personalities - a lack of vision of what needed to be done."

Most of the more senior managers who had transferred from the former plant had limited experience managing a strongly unionized workforce. Little attention was paid to shop-floor productivity so that over time workers established protective customs and practices which went largely unchallenged by management until the late 1980 s. $^{5}$ The plant developed a reputation at the U.K. national office and CHQ for being "union dominated" and "difficult to manage."

The manufacturing director retired in late 1989 and was replaced by a younger man with international experience, including a recent twomonth spell at CHQ. His mandate was to substantially raise workplace performance so that it would function as an integral part of the company's European manufacturing program. In the meantime, morale among managers and employees remained low as rumours of redundancies and the possibility of plant closure hung over the workplace for nearly two years before a plan was announced to the workforce. ${ }^{6}$

5. Union influence increased because of management inefficiency; it was more a symptom than a cause of low productivity and low quality. Indeed, a record of only one incident of industrial action at the U.K. plant over the past 10 years suggests that the unions were not especially bloody-minded.

6. Concern for job prospects loomed large. Only 42 percent of survey respondents agreed with the statement: "I can be sure of my job as long as I do good work." A far smaller proportion (12 percent) agreed that : "there are plenty of good jobs here for those who want to get ahead." Low morale is indicated by the discrepancies between the company's values document and the culture at the plant, especially with regard to innovation and technical expertise. This is illustrated by responses to the following statements in a 1990 company survey covering 161 administrative, supervisory and management employees. Only 36 percent of respondents agreed that "prudent risktaking is encouraged here." A similarly low proportion (37 percent) agreed that "management here supports an environment for prudent risk-taking." Thus management was seen as risk-averse and reactive rather than innovative and proactive with regard to changing both the internal and external environment. 
And although the new manufacturing director was generally wellregarded, there was little confidence in management as a whole. ${ }^{7}$

These events took place against a background of weak production figures. Interviews with marketing and finance managers revealed two main reasons for this poor performance. First, because there were too few new prescription products being marketed by the corporation, the company's U.K. product portfolio was dominated by mature products with low growth potential. Second, new products being introduced into Europe were not produced by the U.K. plant. This was attributed to the plant's inferior customer service and efficiency record compared to the two major European plants, situated in France and Germany.

CHQ confidence that local management could successfully restructure the U.K. plant was based on their view that the plant's past inferior performance was the result of lacklustre management, inferior systems and powerful unions. Faith in the expertise and leadership of the new manufacturing director, coupled with large-scale changes that would lead to a reduction in the number of "old guard" managers and a further diminution in the power of the trade unions, were seen as the key to future success. Accordingly, corporate management anticipated that an outward-oriented, high-performance culture would replace the parochialism and low productivity of the past. This would be achieved by the manufacturing director carrying out a plan negotiated with CHQ and regional managers based on large-scale investments in new technology and management systems coupled with changes in payment systems and rationalization of bargaining arrangements.

Management's main intentions were to improve customer service levels and achieve substantial unit cost reductions over a short period of time. Specifically, this involved a reduction in product variety concentrating on a narrow range of fluids healthcare products - while simultaneously introducing a computerized materials resource planning system (MRP2) and reducing the number of employees by reorganizing work in all manufacturing units. This was supported by major investments in new technology for fluids manufacturing. A completely revised job evaluation system and pay structure, together with rationalized

7. Lack of confidence in management expertise is suggested by the following findings: only 20 percent of respondents to the company survey referred to above agreed that "this company operated efficiently and smoothly"; a similarly small proportion of managers and supervisors (24 percent) concurred with the view that "management really knows its job"; the same proportion (24 percent) agreed that "you always know where you stand with this company." 
bargaining units, also formed part of the U.K. plant's strategic plan. The main aspects of this are briefly touched on below.

Downsizing and automation of the fluid products' packaging lines were integral to achieving success. According to the regional president, the U.K. plant was over-manned in comparison with its German and French counterparts. Whereas the reduction in indirect employees could be achieved gradually, changes in work organization was seen as a fairly immediate means of facilitating a reduction in the number of direct workers. Thus, in March 1990, management informed employees of its plans to reduce the number of workers by 160 . The bulk of these (133) would come from the fluids and dry goods' sections of pharmaceutical manufacturing. These reductions were to be achieved largely by reorganizing work roles, particularly by eliminating repetitive work through automation and by broadening the content of remaining jobs. Teamworking would effectively dissolve demarcation lines.

Since nearly two-thirds of the $\$ 5$ million capital investment was earmarked by CHQ for automating the fluids' packaging lines, this project was seen as central to the competitive future of the plant. The plan was to replace the existing technology with automated fluid packaging machinery, which would facilitate a reduction in the number of employees in the packaging section by 64 percent (from 119 to 43) within a period of 15 months.

The introduction of an integrated job evaluation system, i.e., one that covered all manual and clerical workers (who were represented by a different union) in a single system, was seen as a necessary basis for pay and bargaining unit reform. It would permit rationalization of disparate procedures and provide an incentive for employees to take on enlarged jobs. And by drawing the unions representing semi-skilled (100 percent density), skilled (100 percent density) and clerical workers (75 percent density) together under a common payment system, they could be encouraged to bargain as a single unit. In addition, technical workers might be encouraged to opt out of the union. Management was aiming to encourage these employees to accept staff status by transferring them to the regional payment structure. This would result in higher pay, a bonus, and private medical insurance, at the cost of employees losing their normal entitlement to overtime and termination of the recognition and procedural agreement with the union.

In sum, U.K. plant management was introducing fundamental changes that broadly supported a Just-in-time production strategy. This included a more focused approach to manufacturing and changes in technical systems - MRP2 to ensure more efficient inventory and 
scheduling of output - and fluids automation to boost productivity. Complementary procedural changes in people management included job evaluation and pay and bargaining unit reforms.

\section{The South African Subsidiary: Restricted Innovation in a Local Market}

CHQ viewed the S.A. subsidiary mainly as a stand-alone operation serving a small, low growth market. PH and other pharmaceutical companies had benefited from a laissez faire regulatory environment in South Africa. According to one report (Finance Week 1992: 18), drug prices in South Africa were higher than virtually all major Western countries. However, the government and health-care funds were moving to de-list certain high-priced drugs for government tenders in favour of generics, and a massive investment by a locally-owned pharmaceutical company in generic drug production was underway. A new strategy was clearly required.

In the meantime, control of the subsidiary was entrusted to local management with little direct supervision from CHQ. Corporate management was however sensitive to one particular aspect of the subsidiary's operations: the risk to $\mathrm{PH}$ 's corporate image posed by potential international media coverage of the alleged ill-treatment of black and "coloured" workers. For PH was one of around 200 U.S. corporations that continued to operate in S.A. during the apartheid years. How the company treated its "coloured" and black workers were issues raised at shareholder meetings in the U.S. Local employees were also sensitive to the issue, for they feared that the company might sell out. As a shop steward explained: "We wanted to safeguard ourselves against a new management closing the facility and then re-employing people on lower wages and no benefits." As we shall see, labour-management relations continued to be a critical issue following the transition to democracy.

The South African manufacturing facility had been established over 25 years earlier. In the mid-1980s, CHQ had encouraged subsidiaries to adopt the just-in-time production system. S.A. plant management had improved the quality and timeliness of bottle and packaging supplies from local firms and attention had been paid to reducing stock levels through computerized scheduling. These changes, together with some investment in automation, had facilitated a gradual decline in the workforce from 230 employees in 1981 to around 160 employees in 1992 where workforce numbers stabilized. So-called quality circles (which included workers from adjacent sections) had been established under a previous manufacturing director but they had withered through lack of 
management attention. Over 90 percent of the subsidiary's output was sold locally. In the 1990s, prescription drugs accounted for about 40 percent of sales and a further 30 percent derived from over-the-counter health care products. The remaining 30 percent comprised confectionery products. The facility gained a reputation for being relatively profitable and well-managed; however, as hinted at above, it faced the problem of limited product markets and incipient employee relations problems arising from major political changes.

In response to the product market problem, the subsidiary general manager (who had been at the helm for over 15 years) and his senior colleagues favoured expansion through developing alliances with local companies to produce low-priced items aimed at the low-income, mass market. CHQ, however, was cautious about supporting such ventures, in part because of failures at other subsidiaries, but also because of the damage it might do to PH's reputation for quality products, a characteristic which allowed it to charge premium prices. In 1995 there was a change in senior management (i.e. CHQ's) attitude, giving subsidiary management more discretion to develop local products. However, CHQ argued that it was premature to make any substantial investment in pharmaceuticals in S.A. given government intentions to control drug prices. The prevailing level of violence and the potential for political instability was also of concern. CHQ had meanwhile committed funds to the establishment of a new confectionery plant which replaced the existing facility in Johannesburg. This had to be successfully commissioned before any further large-scale investment would be considered. CHQ stated that they were considerably more optimistic about growth in the local confectionery market than in pharmaceuticals. This was not surprising since confectionery sales and profits were growing at over twice the rate of pharmaceutical products.

Despite only one recorded incident of industrial action - a sit-down in the canteen in 1988 - management was concerned about the potential militancy of younger employees, some of whom were known to be African National Congress supporters. This reflected the tense political situation which can be briefly described as follows. Nelson Mandela had been released in 1990, followed by the legalization of the African National Congress and the dismantling of apartheid legislation. In March 1992 (at the time of the fieldwork) white referendum results favoured continuation of constitutional talks which paved the way for a dissolution of the whitedominated parliament and the scheduling of elections based on universal suffrage in April 1994. These events heightened black and "coloured" workers' expectations leading to widespread strikes which in turn were reflected in institutional changes, particularly the rise of shop stewards 
and workplace bargaining (Joffe et al. 1995). Although this movement was not yet evident at the S.A. plant, management began to plan for it by introducing employee participation as a way of giving a direct voice to workers in decisions that affected both their work and plant performance. The main avenue for dealing with demands by labour would be to continue to act in a socially responsible manner and to reform labour relations arrangements as described below.

The general manager and his colleagues wanted to build on the subsidiary's strong reputation, both within the corporation and in S.A. more generally, as a leader in social responsibility issues. This reputation was forged during the apartheid period in response to the Sullivan code and the subsequent Statement of Operating Principles for South Africa (SOPSA). ${ }^{8}$ These codes required U.S. companies operating in S.A. to contribute the equivalent of 12 percent of total annual payroll to social responsibility programs for black, "coloured," and Asian employees both within the subsidiary and in the local community. The general manager's low key, yet serious commitment to community assistance continued into the post-apartheid era at an estimated cost of $\$ 3$ million a year, most of which was channelled into community programs.

Management's approach was to emphasize organizational and cultural change in the direction of increased communication and employee participation coupled with more employee responsibility and accountability. This was seen to be necessary if plant performance was to be improved under an anticipated regime of lower cost, lower priced goods. The manufacturing director, who had been promoted to the role about six months prior to the commencement of the fieldwork, established a program designed to boost productivity and offset the increasing quality assurance costs associated with government medical council controls. This would be achieved by direct employee participation in group problem-solving on immediate work-related problems, supported by appropriate training. He also emphasized the need for industrial relations reform as a means of maintaining harmonious relations between management and employees.

8. See Beaty and Harari (1987) for details of the Sullivan code which initially encouraged social responsibility programs. Participating firms were audited annually by an international consulting firm. If a company was rated three (the lowest on a three-point scale), its policies probably violated U.S. law (which applied to U.S. companies in South Africa), and could result in prohibition from operating in that country. Under Sullivan and its successor, the SOPSA code of practice, PH consistently received the highest rating. 
The chosen vehicle for increasing employee involvement was a program known as "Green Areas" with suitable preparation achieved via a core training program aimed at providing communication skills training for all manufacturing employees. This was to be supplemented by further training in "business basics." Green Areas is a direct form of participation involving regular meetings of work groups aimed at assisting their supervisors to identify problems and seek solutions in a formalized manner. The program is predicated on producing higher levels of employee involvement and commitment by giving workers a sense of ownership in problem definition and resolution. The mechanisms for achieving higher motivation and productivity include more two-way communication between management and employees, greater worker involvement in decision making, development of more interesting and challenging work roles including better use of skills, and employee recognition.

The planned major reform of industrial relations arrangements reflected the strategy of the chemical industry employers, who were attempting to establish a two-tier bargaining structure with minimum rates and conditions set by industrial council agreement, supplemented by plant-level bargaining. This would include appropriate procedures detailing the rights and obligations to be accorded union representatives (the union secretary and shop stewards). In previous years, manual employees' wages and conditions were regulated by a regional bipartite industrial council whose decisions constituted minima. These were supplemented by additional wages and conditions decided unilaterally by management. $\mathrm{PH}$ was relatively generous compared to comparable firms. A works committee comprising employee representatives (not shop stewards) and managers acted as a channel for communications and airing of grievances. This structure was consistent with PH's traditional paternalistic approach to industrial relations, since, beyond the industry minima, all major matters pertaining to employees required the managing director's approval, subject only to these being within corporate guidelines. ${ }^{9}$ Management was aware that paternalistic, consultative industrial relations arrangements were anachronistic and so was keen to stem worker militancy by encouraging the development of shop stewards under the control of a small, regional, conservative union. In addition, resources were set aside for industrial relations skills training of all stewards, supervisors and manufacturing managers. Management also

9. Many problems that were articulated at work were of an individual nature, and frequently related to off-the-job circumstances. The general manager had in the past made decisions on a case-by-case basis which tended to inhibit the development of HR policy and universalistic rules. 
promoted the company's public image as a supporter of black advancement (through the social responsibility program).

In summary, S.A. management was attempting to move the plant from being a "local implementer" of corporate policy to eventually being a regional "strategic leader". This was predicated on developing relations with local firms to produce products more suitable for the emerging lowpriced domestic and adjacent markets. Management was, however, restricted by $\mathrm{CHQ}$, both in pursuing local strategy and in regard to financing further investment in pharmaceuticals. We therefore coined the term "restricted innovator" for the SA workplace. With limited resources, local management's focus has been on improving manufacturing performance through better people management. This has taken the form of direct employee participation, decentralized bargaining, and continuing support for social responsibility programs.

This experience contrasts with that of the U.K. plant where large-scale change has been driven by CHQ rather than local management. The aim has been to move the workplace from being a "local implementer" towards becoming "a strategic leader" in the supply of liquid products for the European market. As noted above, CHQ - first working through the U.K. national office and subsequently through the European regional centre - formulated plans for resourcing and effecting fundamental changes in manufacturing. Local management was attempting to comply, reducing the product range, introducing MRP2, automating liquid manufacturing, and reforming industrial relations. The industrial relations manager and his team played a pivotal role in ensuring that these changes were implemented without resort to open conflict. This differed from the S.A. plant, where change was more incremental, the union less powerful, and where the manufacturing director was more familiar with the workforce than his relatively new U.K. counterpart.

\section{IMPLEMENTING CHANGE}

In this section we analyse differences in the scope and pace of change at the two plants. In both cases, leadership and detailed control of the change process was devolved to workplace management. The respective manufacturing directors were required to account quarterly to CHQ for expenditure and progress in relation to budget plans agreed on an annual basis. There were, however, two major differences in the change control processes. First, in the absence of a European director at the time, responsibility for implementing the MRP2 scheduling program was in the hands of the U.K. national finance director. In contrast to very occasional visits by CHQ managers to the S.A. plant, the U.K. finance 
director visited the U.K. plant regularly. Secondly, because the U.K. manufacturing director was centrally involved in the wider European manufacturing restructuring program, information about progress at the U.K. plant was informally discussed with European plant directors. In short, although corporate management did not take a more direct role in the change process in the U.K., change was more directly supervised and more open to higher level management discussion than in S.A.

In implementing change, the manufacturing directors were assisted by their respective subsidiary HR managers, both of whom played critical roles in the change process. In shaping industrial relations reform, they contributed to the strategic direction of workplace relations and, through their contacts with shop stewards and union officials, these managers promoted and legitimated the change process. A critical difference was that in S.A. this legitimizing role was extended through implementation of the social responsibility program, while in the U.K. legitimization was deepened through regular consultation and brokering of compromises between line management and the unions.

\section{The U.K. Plant: Transformative Change}

Line managers were split over whether so many changes should have been introduced simultaneously or on a more incremental basis. Some managers believed the approach adopted was less effective than a more ordered, sequential strategy. As one manager remarked: "the workload is crushing. There are so many things going on here. We are fighting on so many fronts. Frankly, I don't know whether we can succeed." Most line managers believed that they had no option: "We are coming from behind having had little incentive to change and having lost several years by having to cope with the closure of the [second pharmaceutical] plant. The critical question is: can we close the gap on our competitors in time?" Given this background, we consider how they fared by looking at each of the change initiatives in turn.

\section{Scheduling and the Introduction of MRP2}

At the time of the fieldwork, MRP2 had been running for nearly a year. Senior line managers were not confident that it would succeed. As a manager commented:

there's a lot being done to change things in the plant so some key people don't have MRP2 as their priority while others don't have a good enough grasp of it... There's a great deal of involvement at [U.K.] director level but senior [plant] management aren't walking around trying to get feedback from the staff and the shop floor. The directors should be trying to coordinate it better and be around more. Also, the training hasn't been too good, 
basically it's the unit managers who do this and some of them aren't clear on a lot of the principles so it's just not happening.

Another senior manager expressed his doubts as follows: "I really don't know whether we will get it [the MRP2 project] going properly... I don't know why they didn't introduce it in selective areas, like in fluid packaging where they really need it. Also I'm not sure that having the Director of Finance as the torchbearer for the project is a good thing. We wanted someone from here to assume that role but they [the directors] disagreed."

A year later, however, management was claiming success; indeed, the project was nearly completed with only refinements to be made. According to the manufacturing director: "I reckon if you go round the factory you will find that 98 percent of people would say we have achieved our goal... There is behavioural change, the numbers are coming up fast and people are believing them. Marketing and manufacturing are working to a common set of numbers." A unit manager also responded enthusiastically: "It's been a tremendous success but it's diluted the amount of effort we could put into the fluids automation project. We've implemented all the elements as planned... We're beginning to reap the benefits of the system: increased production stability - we believe the numbers given by marketing and planning. There's more consistency between forecasting and scheduling and we can see problems [production bottlenecks] coming."

In short, against a background of considerable manufacturing unit parochialism, inter-unit tension and demands of other projects, this major initiative was succeeding, albeit some six months outside the planned time frame.

\section{Reducing the Labour Force and Achieving Labour Flexibility}

Downsizing and increasing functional and numerical flexibility had not yet been completed. Management and unions were nevertheless pleased that substantial labour force reductions had been achieved solely through natural attrition and voluntary redundancy and without industrial conflict. Thus, in mid-1991 there were 543 manufacturing employees. By 1993 the number had been reduced to 493 and by mid-1995 there remained 300 workers in this category. The number of direct employees initially declined most rapidly, followed by faster reductions in indirect workers. Bearing in mind management's aim of reducing the number of employees by 130 in two years, the results indicate that 94 of the planned 130 redundancies (72 percent) had occurred within that period. More generally, the number of direct workers rose again as some indirect employees were transferred to direct status and more direct workers were 
employed to deal with the greater volume of sterile production arising from the transfer of sterile manufacturing from the German affiliate. Nevertheless, by the end of 1993 (the planned completion date) there were nearly 20 percent fewer direct workers employed in pharmaceutical manufacturing. This reduction was less substantial than for indirect workers whose numbers declined by slightly over a third (33.7 percent) between 1988 and 1993.

With regard to the reduction of labour in the fluids' packaging section, the workforce had been reduced from 119 to 53 employees, only 10 employees short of management's target. The manufacturing director commented: "It doesn't worry me that we haven't reached the level we set ourselves. Because we haven't yet confirmed that we can operate on the projected numbers. So, I'm quite happy to go another year with ten socalled flexibility operators..."

Although workers had accommodated to double-day shift-working without any major problems, commissioning new technology had taken more time than anticipated. This resulted in interruptions to production which necessitated weekend working. This was opposed by a minority of workers. It also meant continuing high overtime costs. In addition, because management had underestimated the resources necessary to commission the new equipment, a greater burden fell on fitters and electricians whose limited training on the new machinery was a source of frustration to them and to management.

Line managers also claimed that employee flexibility and teamworking were less extensive than initially anticipated, this being mainly attributed to two factors: the context of job reductions, which led workers to be more guarded about granting other workers access to the work that they normally undertook; and limited incentives to take on new tasks, since the new job evaluation system had not yet been fully implemented..$^{10}$ Fitters were a case in point. They were now expected to assist operators with assembly line clearance checks, monitoring quality, moving products or components and assisting with line washouts in addition to machine repair and maintenance. But, as yet, they received no additional pay. Similarly, team leaders were initially expected to help operators on a range of duties, but the latter, through their union, opposed this intrusion into their domain. So it was agreed that team

10. The view from the HR department was more positive. According to one of the managers: "I am happy with the flexibility so far. We're not looking for massive flexibility; that is not needed given the technological division between different product groups - fluids, drys and so on..." 
leaders would only assist operators in peak load times and in emergencies.

Management further compromised on the question of job flexibility by agreeing to include a new job title - that of senior operator between the operator classification and team leader. Operators were unwilling to undertake some of the new tasks included in the job title (e.g., line clearance checking, quality monitoring, problem solving and training).

The training manager argued that the problem of job flexibility was not only a matter of incentives but also one of competence and hence appropriate training. He maintained that: "There's too much ad hoc training to fit what is shown to be a deficiency. Management are only willing to pay for training when problems arise. This is why in the warehouse area where five jobs have been combined into one job description management aren't getting what they could have in increased flexibility."

\section{Job Evaluation, Pay System and Bargaining Unit Reform}

A management-union working party had been established and it reported on plans for a new job evaluation system which would underpin a new performance-related pay system. The unions welcomed the opportunity to participate in the evaluation process, however there was little support for the principle of pay for performance.

Steady progress was made on the integrated job evaluation scheme so that, by the end of 1991, all of the approximately 140 jobs had been evaluated, with salary levels being allocated to most new job titles. The appraisal system and merit element comprising one percent of pay had been approved by management and unions and began to be applied to shop-floor employees that year. However, five years later, reluctance to accept merit as a basis for wage increases remained. The merit element had not been increased and only workers who had tardy attendance and discipline records failed to receive the average one percent merit increase each year. Regarding procedure, employees had the right to be accompanied by their shop steward in attending their initial performance appraisal, but employees rarely took up this option.

Discussions with the unions continued regarding bargaining unit rationalization, resulting for the first time in joint negotiations (involving the service workers' union, its clerical branch, and the two craft unions) for a new annual collective contract in 1991. By June 1993, the engineering and electrical unions had amalgamated nationally, paving the way for closer cooperation between the craft unions in the workplace. 
Meanwhile, management aimed to disband the professional and technical branch of the service workers' union, a process that was accomplished two years later. The union agreed to relinquish its right to collective bargaining. Current employees were given staff status and received higher benefits. Under the agreement, they could remain union members and were permitted to retain the right to union representation in the grievance procedure.

In summary, the U.K. plant was in the process of transformation. Management viewed the introduction of the new scheduling system and the fluids automation projects as successes. MRP2 was certainly making a difference to customer service levels and management had reduced labour in line with CHQ's strategic plans, although line managers were not completely satisfied with employee flexibility and teamwork. Some changes had not been planned for and were under-resourced, particularly in the training area. There were also some unanticipated costs. Management overload and workforce anxiety over future employment prospects put a brake on the pace of change.

\section{The S.A. Plant: Incremental Change}

Compared with the U.K., there was less pressure for change and more limited resources at the S.A. site. Moreover, a new manufacturing director, relatively inexperienced, had yet to establish his reputation as a workplace leader. Accordingly, incremental change was adopted in the form recounted earlier: a program of employee participation and industrial relations reform.

\section{Employee Participation}

The direct employee participation initiative known as Green Areas had been operating for nine months when the fieldwork was undertaken. All manufacturing managers, supervisors and employees had attended the three-day Interface course, which was provided in-house by a consulting company. Training focused on developing complementary skills for superordinates and subordinates and aimed at changing behaviour without necessarily having to go through a process of attitude change. ${ }^{11}$ However, the course was also intended to encourage a culture

11. The specific skills include: "How to give instructions; how to clarify instructions. How to introduce change; how to co-operate in a change situation. How to recognize dependable/reliable performance; how to ask for feedback on work performance. How to encourage expressions of opinion/offer a suggestion. How to correct unacceptable work or work habits; how to respond to criticism. How to respond to an employee complaint/grievance; and how to raise a problem/grievance." (Training document n.d.) 
based on shared values and norms. Around a third of shop-floor employees attended a four and a half-day basic business course (entitled "Business for Profit") while the eight shop stewards participated in a threeday industrial relations course (entitled "Justice for All") organized under the auspices of the regional industrial council. ${ }^{12}$ With this preparation and with the agreement of the union, management held meetings to explain the meaning of Green Areas to all shop-floor employees. The manufacturing services manager was given the responsibility of coordinating and fostering the program.

Green Areas was piloted in the dry and liquids departments and then introduced elsewhere, comprising ten groups in early 1992. The goal was to extend the Green Areas into other manufacturing departments, with support from a refresher interface course. A recognition scheme was also planned. This would reward participants for successful performance and was developed and being used by one of the company's local suppliers. ${ }^{13}$

Although no formal assessment of the program had been made, the manufacturing director was pleased with progress thus far. ${ }^{14}$ Responses to our survey confirmed that workers were relatively satisfied with the program. Thus, when asked their opinion of the program, 62 percent of the 60 percent of respondents who claimed to participate in Green Areas answered affirmatively (defined as registering six or more on a nine-point scale $[1=$ very bad through to $9=$ very good], the median score being seven). Close to half of the employee respondents (47 percent) reported having more say in decision-making than two years earlier (compared to 42.9 percent who reported "about the same" and 10.2 percent who stated that they had less influence). On the other hand, dealing adequately with

12. These training programs were in addition to others covering the law (130 employees), health and safety (60 employees) and team-building (20 employees). Total training amounted to an average of approximately 18 hours per shop-floor employee, per year, over a three-year period.

13. This involved a points system geared to particular goals, for example, that of the Green Area scheme. It enables participants to obtain consumption goods including consumer durables, which could be obtained by accumulating and saving points over time.

14. This was summarized in a company document and included: a high level of worker involvement; improved communication within and between departments; problems being brought to the attention of the managers more readily, and solutions provided by employees; employees responding favourably to more responsibility and accountability for their actions; less resistance to multi-skilled training and employees being more open-minded and cooperative; better use of skills acquired from other training programs; more positive attitudes and behaviour towards productivity, quality and safety; and improved attendance at work. 
employee requests was more problematic. Thus, only around a third (34.7 percent) of respondents believed that management had been taking more notice of employee problems and complaints than two years earlier. Interviews with managers indicated that a recurrent problem was the additional workload Green Areas placed on management and the need for stronger senior management commitment. For example: "It [Green Areas] hasn't been very successful in part because managers haven't had enough time to action suggestions so there's been a decline in interest... More simple problems are resolved through these meetings but workers would say that long-standing issues aren't addressed... Also workers don't see that functional managers are committed to Green Areas; they don't see them coming along and showing their support."

The Green Areas program was contributing to lower line managers' dissatisfaction. They were expected to respond quickly and effectively to suggestions but were not being compensated for the additional burden. As noted above, some managers avoided the issue by not following through as required. In addition, it was not enough for senior line managers to support the program. They needed to be seen to be actively championing implementation of the scheme.

In sum, despite problems, Green Areas was by and large having the desired effect of developing a more participatory and productivityoriented relationship with shop-floor employees. However, there was as yet no basis for concluding that it had improved productivity or quality. Indeed, this would be difficult to prove given the presence of other factors, particularly overcapacity and the cyclical nature of pharmaceutical production.

\section{Industrial Relations Reform}

Management had discussed their intention to introduce workplace collective bargaining with the union secretary. The secretary was keen to shore up the union's position in light of a possible challenge to union coverage by the much larger Chemical Industry Workers' Union. The secretary agreed to organize elections for shop stewards as a prelude to the introduction of annual workplace bargaining. Of the eight stewards who were elected, three workers had not previously been works committee representatives. The stewards were, however, inexperienced and lacked a unifying leader. Indeed, one of the most influential stewards was highly critical of the union secretary, which made the union's position in the plant more precarious. A further complication was that the union secretary was not well-regarded by management. The manufacturing director observed that: "[The union secretary] doesn't have much of a clue. We lose him when we get into anything a bit 
complicated. It's not easy negotiating with inexperienced stewards and an ineffective union secretary." On the other hand, there was no discernible demand for an alternative union. Meanwhile, management introduced procedures giving the stewards representation in handling grievance and discipline cases, the final step concluding with union secretary participation. Shop steward training was also foreshadowed under the aegis of the industrial council.

It was one thing to introduce formal changes, and another to overturn custom and practice. Most grievances and discipline cases involved specific individuals, so that workers continued to look to senior line managers for solutions. ${ }^{15}$ However, things were changing. As a senior manager noted: "the legacy of paternalism is difficult to erase. Until recently there was the feeling among workers that they could go to the [General Manager] to sort their problems out because he would understand. [A senior manager] and I worked to stop this kind of approach."

In summary, workplace change was implemented in both plants broadly in accordance with management plans. In the U.K. plant, we described change as transformative for it was substantial in scope and introduced relatively rapidly, although some senior managers would have preferred the changes to have been introduced even faster. In S.A., change was incremental, being confined to human resource innovations and introduced by local management without any significant funding or other form of support from CHQ.

This contrast in experience is directly related to the strategic position of the two subsidiaries of which the two plants are a part. The U.K. affiliate was being drawn into a network of production centred on the emerging EU market. It was part of a broader, integrated plan for succeeding in a large, important market. Accordingly, change was more strongly supported and monitored by senior corporate management, even though local management was given a good deal of autonomy in the manner in which change was introduced. The S.A. affiliate, located within a small local and regional market, was judged to be relatively insignificant as a pharmaceuticals manufacturer so that resourcing was limited. Local management was not autonomous in deciding product strategy and CHQ was sensitive to any change in human resource policy that might bring adverse publicity to the corporation. On the other hand, local

15. Of the 28 grievances and disciplinary cases that occurred over a two-and-a-half-year period (1989-92), 11 were concerned with disputes over alleged improper performance of duties or neglect of procedures, and a further 11 involved conflict regarding alleged unauthorized absences or lateness. 
management was free to pursue changes in human resource management practices described earlier. In short, while U.K. management had greater resources to effect change, their more central strategic position within $\mathrm{PH}$ corporation meant more monitoring and less autonomy from senior management. In the case of their S.A. counterpart, the latter's autonomy was circumscribed more by lack of resources than control from above.

\section{CONCLUSION}

In this paper we have demonstrated that in spite of some similarity in the broad direction of change - toward workplace arrangements compatible with just-in-time production - shop-floor change in two subsidiaries in the same MNC was substantially different. In the case of the British plant, we have shown how transformational change was strongly related to the changing position of the workplace - from being a significant local supplier to becoming a "strategic leader" in the supply network serving the large European market. The South African subsidiary, and its workplace, were in a quite different position vis-à-vis corporate headquarters. Local management was attempting to transcend the limits of a small, increasingly competitive market by entering into low-cost product development. However, they were restricted by their small size and limited resources, which in part reflected corporate management's cautious approach to strategies that might compromise the company's image as a premium quality provider. Moreover, there was little enthusiasm for large-scale pharmaceutical investment in a politically volatile and economically uncertain, South Africa. Accordingly, in contrast to the U.K. plant, this "local innovator" introduced incremental change, designed mainly to tackle actual and anticipated local problems that were closely related to major political developments in South Africa.

These findings suggest that the strategies and resources available to local management depend on the strategic position of the subsidiary. This in turn depends on perceptions and evaluations of corporate management, contained in corporate strategy documents and in the dayto-day discussions of senior executives. It is the latter that local management can most easily influence by pursuing innovative policies in constantly changing contexts. For example, in the U.K., morale plummeted in early 1996 when it was rumoured that corporate and regional managers had recently decided that the plant would not survive beyond the year 2000. At the same time, the rationalization of manufacturing was beginning to open up opportunities for the S.A. plant 
to supply small volume, niche products to the European market. CHQ was starting to show more interest in the S.A. affiliate.

Having developed a strategy in accordance with corporate requirements, local factors are important in accounting for differences in the processes and outcomes of workplace change. These include historical aspects of the workforce and management. We noted for example, that these resulted in considerable compromise over the pace of change and worker flexibility at the U.K. plant, and limited management enthusiasm for employee participation at the S.A. workplace. In both cases, lower level management was unenthusiastic about change, albeit for different reasons. In the U.K., this was because the change program was so large and challenging and there was no certainty about future employment. In S.A., managers were expected to undertake additional work associated with the employee participation program in a context where insufficient support was being demonstrated by senior management.

In sum, both global (corporate headquarters) and local (subsidiary management) factors contribute to workplace change but they appear to do so in ways that are patterned according to the strategic position of the subsidiary and in relation to specific constellations of local factors. These together determine the scope, pace and outcomes of workplace change.

Turning to the implications of our findings, it is important to develop a more theoretically coherent characterization of the role of local factors, the way these are embedded in local contexts - political and economic - and their impact on workplace change. A more comprehensive theoretical framework is also needed. Thus, we noted the development of a regional centre in Europe. The role that these centres play in global corporations will affect the status of subsidiaries and complicate the relationship between workplaces and corporate headquarters. We also noted that there was little collaboration between subsidiaries, although corporate management was beginning to encourage inter-subsidiary communication on product specialization and capacity utilization. These two tendencies, together with the growth of strategic alliances, suggests conceptualizing subsidiaries and their workplaces as elements in a network of relationships. Thus, future research requires more complex models of the different parts of the large corporation that influence workplace change. Furthermore, typologies of corporations particularly in relation to processes of globalization - and subsidiaries in a variety of strategic positions and with varying amounts of resources and competencies - will have to be elaborated. 
Finally, if research on change is to be meaningful and yield policyrelated conclusions, it needs to be conducted at a variety of levels that capture the starting points, change dynamics, and the end points of the most significant workplace change processes. This suggests a program of collaborative, comparative and longitudinal research.

\section{- REFERENCES}

BartletT, C. A. and S. GHoshal. 1989. Managing Across Borders. Boston: HBS Press.

BARTLETT, C. A. and S. GHOSHAL. 1990. "The Multinational Corporation as an Interorganizational Network." Academy of Management Review, Vol. 15, 603-625.

BEATY, D. T. and O. HARARI. 1987. "South Africa: White Managers, Black Voices." Harvard Business Review, 98-105.

Collier, X. and P. MARGinson. 1996. "Channels of Influence over Changing Employment Practice in Multinational Companies: A Case from the Food Industry." Conference on 'The Globalization of Production and the Regulation of Labour', University of Warwick, September 11-13.

ECONOMIST, August 1995, 61-62.

ElGER, T. and C. SMITH, eds. 1994. Global Japanization? The Transnational Transformation of the Labour Process. London: Blackwell.

FERNER, A. 1994. "Multinational Companies and Human Resource Management: An Overview of Research Issues." Human Resource Management Journal, Vol. 4, No. 2, 79-102.

FERnER, A. and P. EDWARDS. 1995. "Power and the Diffusion of Organizational Change with Multi-National Enterprises." European Journal of Industrial Relations, Vol. 1, No. 2, 229-257.

FORTUNE. 1991. "The 500 Largest U.S. Industrial Corporations." 109-152.

FORTUNE. 1994. "The 500 Largest U.S. Industrial Corporations." 128-192.

FORTUNE. 1995. "The 500 Largest U.S. Industrial Corporations." F1-F67.

FORTUNE. 1996. "The 500 Largest U.S. Industrial Corporations." F1-F66.

FRENKEL, S. J. 1994. "Patterns of Workplace Relations in the Global Corporation: Toward Convergence?" Workplace Industrial Relations and the Global Challenge. J. Bélanger, P.K. Edwards and L. Haiven, eds. Ithaca: ILR Press, 240-274.

FRENKEL, S. J. 1995. "Workplace Relations in the Global Corporation: A Comparative Analysis of Subsidiaries in Malaysia and Taiwan." Industrialization and Labor Relations: Contemporary Research in Seven Countries. S. J. Frenkel and J. Harrod, eds. Ithaca: ILR Press, 179-215. 
FRENKEL, S. J. and C. ROYAL. 1997. "Globalisation and Employment Relations." Research in the Sociology of Work.Vol. 7, Greenwich, Connecticut: JAI Press.

FRENKEL, S. J. and C. ROYAL. forthcoming. "Workers, Unions and Change in the Global Corporation: Contemporary Experience and Future Possibilities." Globalization and Patterns of Labour Resistance. J. Waddington, ed. London: Mansell.

GHOSHAL, S. and N. NOHRIA. 1993. "Horses for Courses: Organizational Forms for Multinational Corporations." Sloan Management Review, Winter, 23-35.

KEENE, C. et al. 1990. "Agenda for the 90s: Rationalize Manufacturing." Pharmaceutical Executive, September, 44, 48, 50, 52, 54.

KESLER, G. C. 1995. "A Model and Process for Redesigning the HRM Role, Competencies, and Work in a Major Multi-National Corporation." Human Resource Management, Vol. 34, No. 2, 229-252.

MACDUFFIE, J. P. 1996. "International Trends in Work Organization in the Auto Industry: National Level vs. Company-level Perspectives." The Comparative Political Economy of Industrial Relations. K. S. Wever and L. Turner, eds. Madison: IRRA, 71-114.

MARGinSON, P. et al. 1988. Beyond the Workplace: Managing Industrial Relations in the Multi-Establishment Enterprise. Oxford: Basil Blackwell.

MOODY'S INVESTOR SERVICES. 1993. Moody's Industry Outlook: Pharmaceutical. New York.

MUELLER, F. and J. PURCELL. 1992. "The Europeanization of Manufacturing and the Decentralization of Bargaining: Multinational Management Strategies in the European Automobile Industry." International Journal of Human Resource Management, Vol. 3, No. 1, 15-34.

ROSENZWEIG, P. M. and N. NOHRIA. 1994. "Influences on Human Resource Management Practices in Multinational Corporations." Journal of International Business Studies, Vol. 25, No. 2, 229-251.

WiLHELM, W. R. 1990. "Revitalizing the Human Resource Management Function in a Mature, Large Corporation." Human Resource Management, Vol. 29, No. 2, 129-144.

\section{RÉSUMÉ}

Les relations entre sièges sociaux et succursales et les contextes locaux comme facteurs de changement

Durant la dernière décennie, les multinationales se sont repositionnées et réorganisées en réaction à la concurrence globale. Cela 
est surtout le cas dans ces industries où la mondialisation est rapide, telle l'industrie pharmaceutique, où les changements de stratégie, d'organisation et d'environnement local ont été majeurs et ont amené de nouvelles relations entre les sièges sociaux et les succursales. Notre thèse ici est que ces développements ont des conséquences sérieuses sur l'étendue, le rythme et le résultat du changement en milieu de travail.

Nous empruntons à l'école de la stratégie corporative qui prétend que les succursales diffèrent dans leur pouvoir stratégique, dans leurs compétences et dans leurs ressources. Nous nous attardons ici sur les antécédents, motivations, processus et résultats du changement dans les relations au niveau de l'atelier dans deux succursales d'une grande corporation pharmaceutique américaine. L'une d'elle est située en Grande-Bretagne, l'autre en Afrique du Sud. Nous examinons plus particulièrement le rôle du management dans le changement des relations de travail dans ces deux succursales. Nous prétendons que ces relations varient en fonction du rôle des succursales par rapport aux sièges sociaux et aussi en réaction aux facteurs locaux. La filiale britannique se caractérise comme étant un "implanteur local" dans le processus de devenir un leader stratégique, i.e. en améliorant sa position stratégique et en gagnant des ressources (Bartlett et Ghoshal 1989). Essentiellement, le management britannique fut fortement encouragé et supporté dans l'intégration de leurs activités dans une stratégie européenne plus large. Le management africain d'autre part, avec une même approche de départ, a reçu moins d'attention et de support de la part du siège social. Paradoxalement, cela s'est traduit par une plus grande autonomie, mais avec des ressources limitées, un marché local plus petit et l'incertitude politique. Le management sud-africain connaissait alors moins d'encouragement et possédait des occasions limitées pour introduire un changement sérieux en milieu de travail.

Nous comparons l'étendue, la nature et les résultats des changements dans deux milieux de travail. L'approche britannique favorise des changements fondamentaux incluant une attention plus grande à la production et aux changements dans les systèmes techniques - plus particulièrement un inventaire et un horaire de production plus efficaces - et l'automation pour accroître la production. Elle favorise aussi des changements complémentaires en relations industrielles, où le directeur des ressources humaines a joué un rôle clef, incluant des réformes au niveau de l'évaluation des emplois, la rémunération et l'unité de négociation.

La direction sud-africaine, pour sa part, était limitée par le siège social dans sa poursuite d'une stratégie de développement local du produit et dans le financement d'investissement additionnel. Nous avons 
alors désigné le milieu de travail sud-africain d'“ innovateur restreint". Avec des ressources limitées, le programme de changement de la direction locale était plus étroit se concentrant sur l'amélioration de la performance de la production par une meilleure gestion des ressources humaines. Cela s'est traduit par la participation directe des employés, la négociation décentralisée et l'appui continu à des programmes de responsabilité sociale. À l'exception de ce dernier point, la direction des ressources humaines a eu un rôle limité.

Nos résultats suggèrent que le changement en milieu de travail est façonné par les stratégies et ressources disponibles à la direction locale et dépendent de la position stratégique de la succursale. Et cela dépend des perceptions et évaluations de la direction du siège social, lesquelles sont influencées par des facteurs globaux et locaux incluant un aspect historique de la main-d'oeuvre et de la direction. En somme, tant ces facteurs globaux (le siège social) que locaux (la direction et le personnel de la succursale) contribuent à dessiner des modèles différents de changement en milieu de travail.

De façon prospective, notre étude appelle au développement d'une caractérisation théoriquement plus cohérente du rôle des facteurs locaux à l'intérieur d'un cadre théorique plus général. Cela inclurait le rôle des centres régionaux dans la coordination des succursales au sein des multinationales, ainsi que les relations entre succursales. Ces deux sujets suggèrent des modèles plus complexes qui tiennent compte de toutes les parties d'une grande corporation pouvant influencer le changement en milieu de travail.

\section{RESÚMEN}

Las relaciones entre las corporaciones y sus subsidiarias y el contexto local como factores que modelan el cambio en el ambiente de trabajo en las corporaciones transnacionales

Este documento estudia el cambio en el ambiente de trabajo en dos subsidiarias de corporaciones multinacionales. Demostramos como cambios en las relaciones entre la subsidiaria y las oficinas centrales de la corporación reflejan cambios en el poder estratégico y en los recursos de las subsidiarias, así como diferencias de carácter local. Estas diferencias se reflejan en el alcance, ritmo y contenido dela cambio en el ambiente de trabajo. 